\begin{tabular}{|c|c|c|c|}
\hline & \multicolumn{2}{|c|}{ R\&S - RESEARCH STUDIES ANATOLIA JOURNAL } & 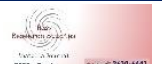 \\
\hline $\begin{array}{l}\text { Research Stydies } \\
\text { Anatolia Journal }\end{array}$ & https://dergipark.org.tr/rs & Vol:3 Issue:4 pp:343-359 & -2 \\
\hline
\end{tabular}

SOCIAL AND HUMAN SCIENTIFIC

Kayabaşı, O. (2020). "Polis Bütünlüğü Üzerine Teorik Bir İnceleme Ve Polis Sapması Sorununa Karşı Bütüncül Bir Yaklașım", R\&S -Research Studies Anatolia Journal, Vol:3 Issue:4 ; pp:343-359

\begin{tabular}{rlll}
\hline \hline Anahtar Kelimeler: Polis Bütünlüğü, Polis Sapması, & Keywords: Police Integrity, Police Deviance, \\
$\begin{array}{l}\text { Örgütsel Polis Bütünlüğü, Örgütsel Polis Sapması, } \\
\text { Teorik Bir İnceleme, Bütüncül Bir Yaklaşım }\end{array}$ & $\begin{array}{l}\text { Organizational Police Integrity, Organizational Police } \\
\text { Deviance, A Theoretical Review, A Holistic Approach }\end{array}$ \\
\hline \hline Makale Türü: & Araștırma Makalesi \\
\hline \hline
\end{tabular}

\title{
POLİS BÜTÜNLÜĞÜ ÜZERİNE TEORIKK BİR İNCELEME VE POLİS SAPMASI SORUNUNA KARŞI BÜTÜNCÜL BİR YAKLAŞIM*
}

\author{
A Theoretical Study on Police Integrity and an Integrative Approach to the \\ Problem of Police Deviance \\ Osman KAYABAŞI ${ }^{1}$
}

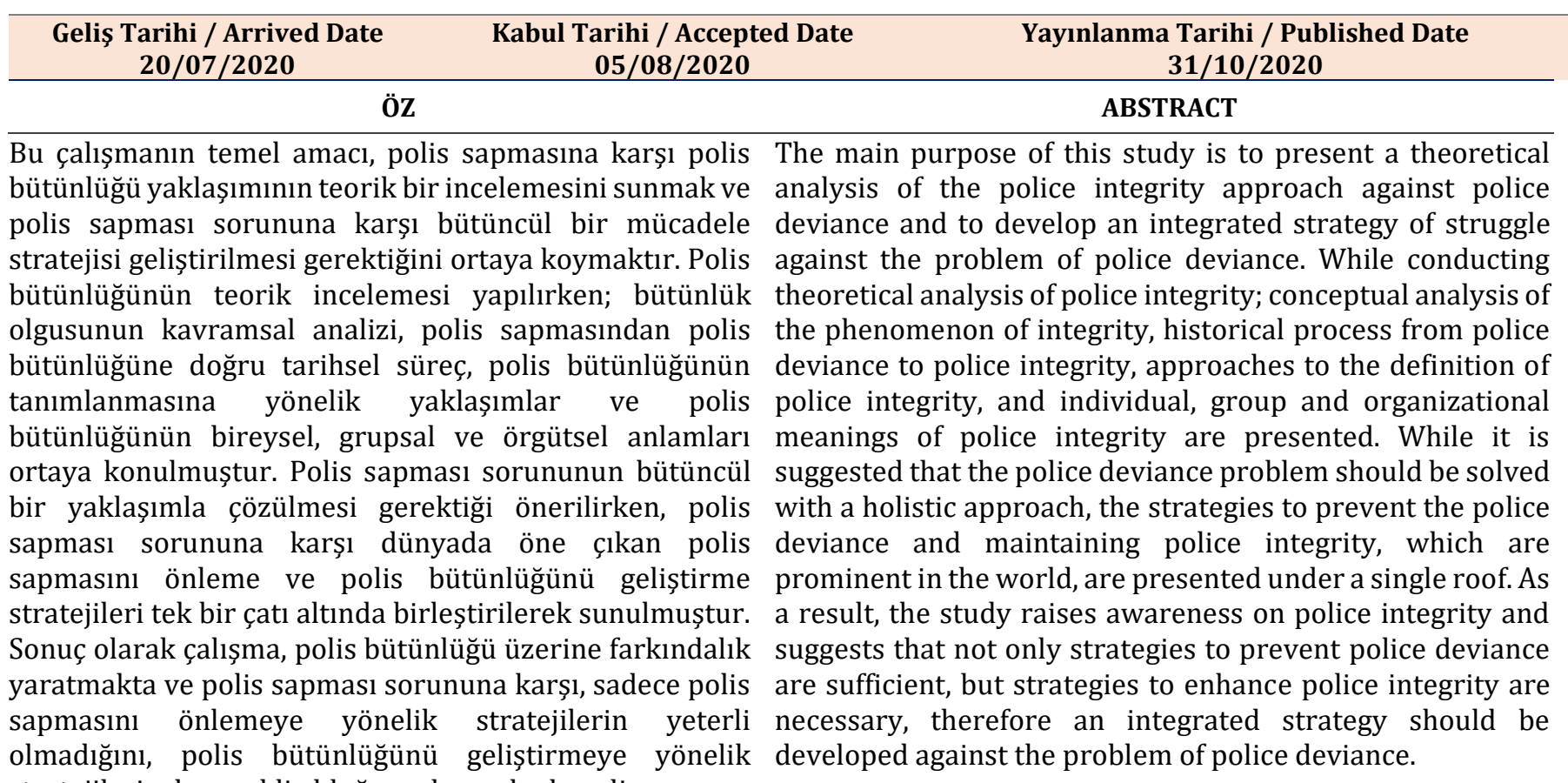

stratejilerin de gerekli olduğunu, bu nedenle polis sapması sorununa karşı bütüncül bir strateji geliştirilmesi gerektiğini ileri sürmektedir.

\section{GíRiş}

Günlük kullanımda bütünlük (integrity), etik (ethics) ve ahlak (morals) kavramları bazen birbirlerinin yerine kullanılabilmektedir. Fakat bu kavramlar birbirlerinden farklıdır. Hem etik hem de ahlak, "doğru ve yanlış", "iyi ve kötü", "erdemli ve kusurlu" arasındaki ayrımı yapabilmekle

\footnotetext{
* Bu çalışma, 29-30 Haziran 2020 tarihleri arasında Gostivar- Makedonya'da düzenlenen "5. Uluslararası EMI Girişimcilik ve İletişim Sosyal Bilimler Kongresi”nde sözlü olarak sunulan bildirinin genişletilmiş ve gözden geçirilmiş halidir.

1 iD Dr. Polis Başmüfettiși, KKTC Polis Genel Müdürlüğü, Mali Suçlarla Mücadele Şube Amiri, osmankayabasi@yahoo.com, KKTC.
} 
yakından ilişkilidir. Etik ve ahlak, neyin doğru ya da yanlış, iyi ya da kötü, erdemli ya da kusurlu olduğu hususunda bir karar vermeyle ilgili meselelerle uğraşan normatif kavramlardır. Ahlak, toplumun, o toplumdaki bireyler için, iyi ve kötü, doğru ve yanlış, erdemli ve kusurlu yazılı olmayan davranış standartlarını ifade ederken; etik, bir grubun veya örgütün tüm üyeleri için geçerli olan yazılı normatif değerler kümesini ifade etmektedir. Böylece hem ahlak hem de etik, arzu edilen ve istenmeyen davranışlarla ilgilidir. Bütünlük; bir kişinin iyi, doğru, erdemli olanı bilmesi; bu bildiklerini bilinçli bir şekilde inanarak, isteyerek, içinden gelerek gerek sözde gerekse tutum ve davranışlarında ayni doğrultuda sergilemesi ve bu düşünce, söylem ve eylemleriyle yaşayarak bütünleşmesidir. Bütünlük, etik veya ahlaki olmayan davranışların yokluğuyla değil, "beklenenden daha iyi olan" etik veya ahlaki davranışlarla ilişkilidir.

Günlük kullanımda bazen bütünlük (integrity) kavramının yerine kullanılan bir diğer kavram ise dürüstlük (honesty) kavramıdır. Bu iki kavram da birbirlerinden farklıdır. Dürüstlük, bir kişinin yanlış yapmış olsa bile doğruyu söylemesidir. Bütünlük ise, bir kişinin inandığı şeyi söylemesi, söylediği şeyi yapması ve yaptığı şeyi sıkıntılı durumlarda bile cesaretle savunabilmesidir. Bütünlük; bir kişinin, kimse görmese bile veya herkes karşısında olsa bile, doğru olan șeyi yapmasıdır. Bütünlük kavramı, bir bireye uygulanabildiği gibi, bir gruba veya bir örgüte de uygulanabilmektedir.

Polis bütünlügü kavramı, polis sapması sorununa karşı alternatif bir çözüm önerisi olarak 1990’lı yıllarda ortaya çıkmıştır. Kısa zamanda benimsenen bu yaklaşım, birçok çalışmanın odağı olmayı başarmıștır. Bu çalışmanın temel amacı, polis sapmasına karşı polis bütünlüğü yaklaşımının teorik bir incelemesini sunmak ve polis sapması sorununa karşı bütüncül bir mücadele stratejisi geliştirilmesi gerektiğini ortaya koymaktır. Bu amaç doğrultusunda çalışmada öncelikle polis bütünlügünün teorik bir incelemesi yapılmıştır. Bu inceleme yapılırken; bütünlük olgusunun kavramsal analizi, polis sapmasından polis bütünlügüne uzanan tarihsel süreç, polis bütünlüğünün tanımlanmasına yönelik yaklaşımlar ve polis bütünlüğünün bireysel, grupsal ve örgütsel anlamları ortaya konulmuştur. Daha sonra çalışmanın amacına uygun olarak polis sapması sorunu bütüncül bir yaklaşımla ele alınmıştır. Bu çerçevede polis sapması sorununa karşı dünyada öne çıkan polis sapmasını önleme ve polis bütünlüğünü geliştirme stratejileri tek bir çatı altında birleştirilerek sunulmuştur. Çalışma, polis bütünlügünün önemine vurgu yapmakta ve polis sapması sorununa karşı bütüncül bir strateji geliștirilmesi gerektiğini ileri sürmektedir.

\section{BÜTÜNLÜK}

\section{Bütünlük Kavramının Kökeni ve Anlamı}

"Bütünlük" (integrity) kelimesi; Latince "integer" (bütün, sağlam, tam) sözcüğünden türeyen "integritas" (bütünlük, sağlamlık, tamlık) kelimesinden gelmektedir. Latinceden Ortaçağ Fransızcasına "integrité" olarak geçen bu kavram, "masumiyet, suçsuzluk, namusluluk, saflık" anlamlarıyla kullanılmış; ardından Geç Ortaçağ İngilizcesine "integrite" (bütünlük, sağlamlık, tamlık) olarak geçmiş ve sonraları "integrity" (bütünlük) şeklinde kullanılmaya başlanmıştır. İngilizce "integrity" kelimesi Türkçeye "bütünlük, tamlık, tamamlık, namusluluk, sağlamlık, doğruluk, bütünleşmişlik, dürüstlük, bozulmamışlık" olarak çevrilebilmektedir (Tureng, 2020).

"Bütünlük" kavramı, çeşitli İngilizce sözlüklerde üç anlamına vurgu yapılarak tanımlanmaktadır. American Heritage Dictionary of the English Language (2020) Sözlügü bütünlügü; "tamamlanmış olma özelliği veya durumu; tamlık, tümlük", "bozulmamış olma niteliği veya durumu, mükemmel durumda olma; sağlamlık", "sağlam ahlaki ilkelere sahip olma durumu veya özelliği; doğruluk, dürüstlük ve samimiyet" olmak üzere üç anlamda tanımlanmaktadır. Benzer şekilde MerriamWebster Online Sözlüğü (2020) bütünlüğü; "özellikle ahlaki veya sanatsal değerlerin kurallarına sıkı sıkıya bağlılık; dürüstlük", "bozulmamış durumda olma; sağlamlık" ve "tam veya bölünmemiş olma özelliği veya durumu; bütünlük" olmak üzere üç anlamda tanımlamaktadır.

“Bütün” kelimesi Türkçede; “(1) eksiksiz, tam”, “(2) çok sayıdaki varlık ve nesnelerin hepsi”, “(3) bozuk olmayan (para)”, "(4) parçalanmamış", “(5) birlik, tamlık” anlamlarına gelmektedir (TDK, 2020). Ayrıca Türkçede "bütünlük" kelimesi; "tam, bitmiş olarak" (Etimoloji Türkçe, 2020),

\section{$\mathbf{R} \& S$}

Research Studies Anatolia Journal

Volume:3, Issue:4, October 2020 
“bütün, tam, kâmil, olgun” (TDH Sözlüğü, 2020) gibi anlamlarda kullanılabilmektedir. Bütünlük, "bölünmezliğin bir sonucu olup, bir değer, olgu, varlık veya nesnenin kendini oluşturan unsur ve özelliklerin bir araya gelmesiyle oluşan bir durum" anlamına gelmektedir (Derdiman'dan akt. Özkaya, 2019: 100). "Bütünlük" kavramı, Arapça ve Osmanlıcada; "külliye, külliyet" șeklinde ifade edilmektedir (Devellioğlu, 1984: 638).

\section{Bütünlük Kavramının Tanımlanması}

Mevcut literatür incelendiğinde, bütünlük kavramı üzerine birçok görüş ve tartışma olmasına rağmen, bütünlük kavramının tanımlanması hakkında fikir birliğine varılamadığı görülmektedir. Bazı yazarlar "bütünlük" (integrity) kavramının tanımını yaparlarken bütünlüğün Latince bir sözcük olan "integritas" sözcüğünden türetildiğini ve aynı zamanda "tamlık" (wholeness), "tamamlanmışlık" (completeness) ve "saflık" (purity) olarak tanımlanabileceği görüşünde olduklarını belirtmişlerdir (Benjamin, 1990; Montefiore ve Vines, 1999; Taylor ve Gaita, 1981). Bu bakış açısına göre bütünlük bir kişiye uygulandığında; "tamlık" anlamında bir kişinin tamam, sapasağlam ve kusursuz olduğunu, "tamamlanmışlık" anlamında bir kişinin kâmil ve olgun olduğunu, "saflık" anlamında ise bir kişinin özünde/fitratında saf, temiz ve bozulmamış olduğunu ifade etmektedir. Bu görüşteki yazarlardan Benjamin (1990: 46) bütünlüğü; "kusursuz, bozulmamıș veya bozulmaz" olarak; Jensen (2009: 18) ise "tam, eksiksiz, bozulmamış, kırılmamış, sağlam, mükemmellik durumu veya hâli" olarak tanımlamıştır.

Bazı yazarlar bütünlüğün bir diğer anlamına, "otantiklik/özgünlük” yönüne vurgu yapmışlardır. Bu tanım, Hamlet'de Shakespeare'in ünlü alıntısıyla aktarılan düşünce ile ilgilidir; "kendine karşı dürüst olmak" (to thine own self be true) (Hamlet, Birinci Perde, Üçüncü Sahne). Bütünlügün bu anlamı kendi vicdanının sesine göre hareket etme ile ilgilidir. Bazı yazarlar ise bütünlük kavramını tanımlarken, bütünlüğün, davranışsal tutarlılık olarak da bilinen söz ve eylem tutarlılığı yönüne vurgu yapmışlardır (Bews ve Rossouw, 2002; Jensen, 2009; Kirkpatrick ve Locke, 1991; Paine, 2005; Simons, 2002, 1999; Simons vd., 2007; Tracey ve Hinkin, 1994; Worden, 2003;). Benimsenen ve sergilenen değerler arasında algılanan uyumluluk, diğer bir ifadeyle algılanan sözünü tutma, bu çerçevede bütünlüğün "sözlerin ve eylemlerin tutarlılığı" yönünü ifade etmektedir.

Bütünlüğün bir bașka anlamı da sıkıntılı durumlar, ayartmalar veya meydan okumalar karşısında bile söz ve eylem tutarlılığıdır (Duska, 2005; Paine, 2005; Posner, 2001; Worden, 2003). Palanski ve Yammarino (2007: 174) kavramsal olarak bütünlüğün sözlerin ve eylemlerin tutarlıllğı yönüne çok benzer olsa da bu şekilde bütünlügün kullanımının, açıkça bütünlüğün gerçekleşmesi için bir koşul olarak olumsuz bir durumun varlığını gerektirdiğini, aksi takdirde sadece sözlerin ve eylemlerin tutarlılığının bütünlüğün bu yönünü karşılayamayacağını belirtmişlerdir. Benzer şekilde Paine'e (2005: 248) göre de bütünlük sahibi kişiler; "bir şey için dik dururlar ve sıkıntı ya da ayartma ile karşı karşıya kaldıklarında da sabit kalırlar." Benzer șekilde Worden, bütünlüğün bu yönünü şu sözlerle ifade etmiștir; "Bütünlüğün ayırt edici özelliği, kendine karşı büyük bir maliyeti olacak olan sıkıntı ya da zorluk ile karşı karşıya kalındığında, ilkeli davranarak taahhütlerine bağlı kalmaktır." (Worden, 2003: 34).

McFall (1987), sıkıntılı bir durumun, ayartmanın, meydan okumanın varlığının bütünlük için gerekli bir koşul olduğunu öne sürmüştür; çünkü bütünlük, iki eylem rotası arasında bir seçim içermelidir. Bu görüşe göre eğer seçim yoksa bir bütünlükten de bahsedilemeyecektir. Carter (1996: 23); "Kaybedecek bir şeyleri olduğunda inançları için ayağa kalkanlara hayran kalıyoruz." diyerek McFall'ın görüşünü desteklemiştir. Palanski ve Yammarino (2007: 174) en azından, sıkıntı veya meydan okumanın mevcudiyetinin bütünlüğün daha belirgin hâle gelmesine neden olacağını, çünkü bütünlük hakkındaki tartışmaların, sıkıntı karşısında bir bütünlük yoksunluğu olayını takip etme eğiliminde olduklarını belirtmişlerdir. Gerçekten sıkıntı, ayartma ya da meydan okuma ile karakterize edilen bir durumun varlığı, bütünlük üzerinde önemli bir etkiye sahip olabilecektir.

Bununla birlikte, bütünlüğün yalnızca sözler ve eylemler arasındaki tutarlılık veya açık bir şekilde verilen sözün tutulması ve savunulması olarak tanımlanması, ayrıca sözlerin ve eylemlerin etik 
veya ahlaki olmayan bir nitelikte olabileceği anlamına da gelebilecektir. Bu çerçevede bazı yazarlar, bütünlüğü, bir kişinin kendi ahlaki değerler setine sahip olması ve sahip olduğu ahlaki değerlere bağlı kalarak hareket etmesi ile ilişkilendirmişlerdir (Cox vd., 2003; Howell ve Avolio, 1995; Koehn, 2005; Lowe vd., 2004; Morrison, 2001; Posner, 2001; Yukl ve VanFleet, 1992).

\section{POLIS BÜTÜNLÜĞÜ ÜZERINNE TEORIKK BİR İNCELEME}

\section{Polis Sapmasından Polis Bütünlüğüne Uzanan Tarihsel Süreç}

Dünyanın birçok yerinde polis sapması bir sorun olarak görülmesine rağmen, bu sorunun nedenleri üzerine ilk bilimsel çalışmaların ancak 1950'li yıllarda ABD'de yapılmaya başlandığı görülmektedir. Bu çalışmaların öncüsü, William Westley'nin 1950'de ABD’nin İndiana Üniversitesinde yaptığı "Violence and the Police" (Şiddet ve Polis) başlıklı doktora tezidir. Westley (1970: 1004) söz konusu çalışmasında, polis sapmasının nedeninin, polislik mesleğinin tehlikeli ve muhalif doğasından kaynaklı, polislerin aralarındaki gizlilik ve sadakat olduğunu ileri sürmüştür. Söz konusu çalışma, polis sapmasını, polis örgüt kültürü teorisi ile açıklayan sonraki çalışmalara öncülük etmiştir. Ne var ki akademik camianın polis sapmasına yoğun bir şekilde ilgi duyması ve bu alanda birçok çalışmanın literatüre kazandırılması 1960'lı yılların sonu ile 1970'li yılların başına denk gelmekte ve ABD’nin özellikle New York Polis Departmanında bu yılları kapsayan dönemde meydana gelen polis yolsuzluğu (police corruption) skandallarına dayanmaktadır (Kayabaşı, 2019: 52).

1960'lı yıllar ABD'sinde polis sapması üzerine öne çıkan bilimsel çalışmalardan biri, Ellwyn R. Stoddard'ın 1968 yllında yayımlanan "Informal Code of Police Deviancy: A Group Approach to BlueCoat Crime" (Polis Sapkınlığının Gayrı Resmî Kuralı: Mavi Mont Suçu için Bir Grup Yaklaşımı) başlıklı çalışmasıdır. Stoddard, söz konusu çalışmasında, polis sapmasının bireysel olduğu tezini ileri süren "çürük elma" (rotten apple) teorisine karşı çıkarak polisler arasındaki sapmanın bireysel olmadığını, polis sapmasının bir grup sapması (group deviation) olduğunu ileri sürmüştür. Bu bilimsel çalışmayı teyit eder nitelikte, New York şehri eski Polis Komiseri Patrick V. Murphy de (akt. Barker, 1977: 354), polislerin birer suçlu olarak doğmadıklarını, fakat mesleki sosyalleşme süreci içinde birer sapkın polise dönüştüklerini vurgulamıştır. Benzer şekilde, Sherman, gözlemlerine dayanarak, polis sapmasının; yasal, kurumsal ve sosyal düzenlemelerin bir sonucu oluştuğunu ve polislerin, patolojik çürük elmalar olduklarından dolayı değil, sadece sancılı bir mesleki sosyalleşme süreci yüzünden rüşvetçilere ve soygunculara dönüştüklerini ileri sürmüştür (Sherman, 1985: 253). Polis sapmasının grupsal boyutta olduğu tezi, elmaların içinde bulunduğu "çürük varil" (rotten barrel) teorisiyle (O'Connor, 2005: 2) de tasvir edilmiştir. Tarihsel süreçte polis sapmasının grupsal olduğu tezini, polis sapmasının grupsaldan da öte örgütsel olduğunu tezi takip etmiştir. Polis sapmasının örgütsel olduğu tezi "çürük meyve bahçeleri" (rotten orchards) teorisiyle (Punch, 2003: 172) de tasvir edilmiştir.

Polis bilimleri literatüründe polis sapması ve polis suçları üzerine özellikle 1960'lı yıllardan beri çok sayıda akademik çalışma yapılmış olmasına karşın, polis bütünlügü üzerine yapılan bilimsel çalışmaların tarihi 1990'lı yıllara dayanmaktadır. 1990'lı yıllarda ABD'de vuku bulan bir dizi olay neticesinde polis örgütlerinde yaşanan polis sapma ve suçları sorunu tekrar gündeme gelmiştir. Rodney King'e karşı uygulanan polis şiddetinin ardından gelişen sürece bağlı olarak Cristopher Komisyonunun (1991) oluşturulması, Mollen Komisyonu (1994) tarafından New York Polis Departmanında yaşanan polis yolsuzluklarının soruşturulmaya başlanması, dikkatleri yeniden Amerikan polisine çevirmiştir.

1990'lı yılların başında ABD'de yaşanan polis sapması sorunu, ABD’nin Toplum Destekli Polislik Hizmetleri Ofisinin ve ABD Adalet Bakanlığının araştırma kolu olan Ulusal Adalet Enstitüsünün soruna farklı bir bakış açısıyla yaklaşmalarına ve polis sapmasını polis bütünlügü perspektifinden inceleyecek, değerlendirecek ve/veya ölçecek projeleri destekleme kararı almalarına sebep olmuştur. Böyle bir ortamda 1995 yılı ve takip eden yıllarda birçok projeye fon sağlanmıştır (Kayabaşı, 2019: 60). Bununla birlikte, bütünlük tartışmaları, geçmişe doğru izi sürüldüğünde "yönetsel etik" teorisine kadar uzanmaktadır. Yönetsel etik, 1940’ta ABD'de Kamu İdare Dergisinin kurulmasından bu yana sürekli ilgilenilen bir konu olmakla birlikte; konunun 
gelişimsel ve sistematik işlenişi 1970’lerden sonra başlamaktadır (Cooper, 1994). Bu alandaki çalışmalar 1990'lı yıllarda hızla gelişmiş; bilimsel araştırmalar, konferanslar ve yeni kurumların kurulması ile desteklenmiştir (Cooper, 1994).

Kamu yönetiminde etik çalışmaları çoğunlukla; dürüstlük, kişisel ahlak, anayasal ilkelere bağlllık, yasalara riayet ve mesleki etik kurallara uygun davranmak gibi değerler ile karakterize edilmektedir (Cooper, 1994). Thompson (1985: 555) yönetsel etiği; "ahlaki ilkelerin örgütlerdeki çalışanların davranışlarına uygulanması" olarak tanımlamıştır. Yönetsel etik teorisinin ilk yıllarında, idari bir davranışın sorumluluğu ile ilgili dış kontrol mekanizmalarının mı yoksa iç kontrol mekanizmalarının mı harekete geçirilmesi gerektiği üzerine şiddetli tartışmalar yaşanmıștır (Cooper, 1994). Dış kontrolün savunucuları, idari sorumluluğu sağlamak için yasalar ve yaptırımlar yoluyla yasama ve idari kontrolün gerekliliğini vurgularken; iç kontrolün savunucuları ise, etik, normlar ve mesleki değerlerin, uygun idari davranışı belirleyen ana faktörler olduklarını ileri sürmüşlerdir (Cooper, 1994). Bununla birlikte, Sykes, iç kontrolün savunucularının bile çoğunlukla kurallar ve yaptırımlar üzerinden ilerlediği görüşündedir (Pagon, 2000). Dış kontrolün polis sapmasını önlemedeki başarısızlığı, odağı iç kontrole kaydırmıştır. Günümüzde polis sapmasının kontrolüne yönelik çalışmaların merkezinde polis bütünlügü ile ilgili (polis bütünlüğünün nasıl tanımlanabileceği, nasıl korunabileceği, nasıl artırılabileceği gibi) konular vardır.

ABD'de polis sapma ve suçları üzerine polis bütünlügü perspektifinden bugüne değin birçok konferans ve seminer düzenlenmesine, bu alanda devlet destekli birçok proje yapılmış olmasına rağmen, literatür tarandığında bu soruna Avrupa Birliği (AB) tarafindan gereken ilgi ve desteğin henüz yeteri kadar gösterilmediği görülmektedir. Polis bütünlüğü üzerine $A B$ bünyesinde uluslararası boyutta gerçekleştirilen konferanslardan en bilineni 2014 yılında $A B$ ve üçüncü ülkelerdeki polis eğitiminin geliştirilmesine yönelik olarak Hollanda'da düzenlenen ve ana teması "Building Police Integrity: A Post-Conflict Perspective" (Polis Bütünlüğünü Oluşturmak: Bir Çatışma Sonrası Perspektifi) olan konferanstır. Bu konferansa birçok ülkeden akademisyenler, polis uzmanları ve polis uygulayıcıları katılmış ve polis sapmasına karşı polis bütünlüğü perspektifi yoğun bir ilgi ile karşılanmıştır.

Türkçe literatür tarandığında, 'polis etiği' (O. Kayabaşı, 2012; Kayabaşı ve Tekiner 2017a) ve 'polis meşruiyeti'nin (C. Kayabaşı, 2012; 2020) yanı sıra, polis bütünlüğü üzerine de bir takım çalışmaların yapıldığı görülmektedir. KKTC (Kuzey Kıbrıs Türk Cumhuriyeti) Polis Teşkilatı Merkez Örgütünün (Kayabaşı, 2017a; Kayabaşı ve Tekiner, 2017b); Merkezdeki Narkotik ve Kaçakçılığı Önleme (Kayabaşı, 2017b), Adli (Kayabaşı, 2018a) ve Trafik (Kayabaşı, 2018b) Bölüm Müdürlüklerinin ve Taşradaki Güzelyurt Polis Müdürlüguünün (Kayabaşı, 2018c) polis bütünlügüunü ölçen çalışmalar yapılmıştır. Küresel boyutta KKTC'deki polis bütünlüğünün diğer ülkelere nazaran ne durumda olduğunu tespite yönelik, KKTC'nin on ülke ile karşılaştırılmasına odaklanan bir çalışmanın (Kayabaşı, 2018d) yanı sıra, KKTC'deki örgütsel ve grupsal polis bütünlügünü karşılaştıran bir çalışmanın (Kayabaşı, 2019b) da yapıldığı da görülmektedir. Bu alanda yapılan en kapsamlı çalışma; KKTC'deki polis bütünlügünü; örgütsel, grupsal ve bireysel boyutları ile ele alan ve alanda yapılan önceki çalışmalar ile birlikte değerlendiren doktora tezidir (Kayabaşı, 2019a). Diğer taraftan literatür tarandığında, ne polis sapmasını polis bütünlügü perspektifinden teorik olarak inceleyen ne de polis sapması sorununa karşı alternatif bir yaklaşım öneren herhangi bir çalışmanın yapılmadı̆̆ı görülmektedir. Bu çalışma ile bu boşluğa odaklanılmıştır.

\section{Polis Bütünlüğü Kavramının Tanımlanmasına Yönelik Yaklaşımlar}

Polis bütünlüğü kavramını, bazı bilim insanları "polis bütünlüğü nedir?” sorusu üzerinden, bazı bilim insanları "polis bütünlügü ne değildir?" sorusu üzerinden, diğer bazıları da bu soruların her ikisi üzerinden tanımlamaya çalışan yaklaşımlar benimsemişlerdir.

\section{$\mathrm{R} \& S$}

Research Studies Anatolia Journal

Volume:3, Issue:4, October 2020 
Polis bütünlüğünün nasıl tanımlanabileceği üzerine değerlendirmede bulunan Vicchio'ya göre, bütünlük sahibi örnek bir polisin erdemleri şunlar olmalıdır: "Sadakat, cesaret, onur, dürüstlük, ihtiyat, güven, kişisel çıkarcılı̆ın olmamasl, zihinsel dürüstlük, adalet, ahlak, ilkeli davranış, sorumluluk ve göreve adanmışlık" (Vicchio, 1997: 3). Diğer taraftan Moore’a göre, "Polis bütünlüğü; yasalara bağlı bir karakter, teknik anlamda güven, tarafsızlık, mesafelilik, kişisel menfaatlerin ortadan kaldırılması, birazcık nezaket ve müșteri duyarlılığını ifade etmektedir" (Moore, 1997: 63). Hickman ve arkadaşlarına göre; "Polis bütünlüğü, polislerin temel değerleri ve etik bağlllıklarıdır ve bu temel değerler ile polis etik kurallarının polislerin davranışlarını nasıl şekillendirdiğidir." (Hickman vd., 2004: 1).

Polis bütünlüğünün nasıl tanımlanabileceği üzerine 1990'lı yılların sonuna doğru sadece ABD'de değil İngiltere'de de birtakım gelişmeler yaşanmıştır. Bu çerçevede 1999 yılında İngiltere'deki "Her Majesty's Inspectorate of Constabulary" (Majestelerinin Muhafaza Müfettişliği) tarafından öne çıkan polis bütünlüğü tanımı şu şekildedir: "Polislikte bütünlük, yetki ve takdirin en yüksek yeterlik, adalet ve dürüstlük standartlarında kullanılmasıdır." (HMIC, 1999: 8).

Polis bütünlüğünü, erişilmiş ya da erişilmemiş bir durum olarak görmektense, bir "süreç" (Goldsmith, 2001: 191), ya da "bir varış noktasından ziyade yolculuğun ta kendisi" (Carter, 1996: 20) olarak özetleyen bilim insanları da vardır. Klockars ve arkadaşları tarafından ise polis bütünlüğünün ne olduğu şu şekilde tanımlanmıștır; "polisler arasında, mesleklerinin hak ve ayrıcalıklarını suistimal etmeye sevk eden ayartmalara karșı direnme normatif eğilimi" (Klockars vd., 2004: 2; 2006: 1). Klockars ve arkadaşları polis bütünlügünü tanımlamanın yanı sıra ölçmeye yönelik çalışmalar da yapmışlardır. Bu çerçevede, çeşitli polis sapma davranışlarının tasvir edildiği varsayımsal senaryolar içeren bir ölçek geliştirmişlerdir. Geliştirdikleri ölçekte on bir adet varsayımsal senaryoya ve her bir senaryonun altında, senaryoları değerlendirmek üzere tasarladıkları aynı yedi adet soruya yer vermişlerdir. Klockars ve arkadaşları (1997) "The Measurement of Police Integrity" (Polis Bütünlüğünün Ölçümü) adını verdikleri bu projelerine 1995 yılında başlamışlar ve proje kapsamında geliştirdikleri polis bütünlüğü ölçeğini; ABD, Hırvatistan, Slovenya ve Polonya olmak üzere dört farklı ülkenin polis örgütlerine uygulanmışlardır. Proje kapsamında 1997 yılında ABD'nin otuz farklı polis örgütünde çalışan 3235 polise anket uygulamışlardır. Böylece hem dört farklı ülkenin hem de ABD içerisindeki otuz farklı polis örgütünün polis bütünlügü düzeyini analiz etmişlerdir. Klockars ve arkadaşlarının söz konusu çalışmalarında ele aldıkları beş temel soru ve bu sorular için çalışmalarının sonunda polis yöneticilerine önerdikleri sorumlu davranışlar aşağıda verilmiştir (Klockars vd., 2006: 11):

Soru 1: Polis mensupları, örgütlerinin resmi kurallarını biliyorlar mı?

Sorumlu davranış: Eğer biliyorlarsa, iyi. Bilmedikleri yerde onlara öğretin.

Soru 2: Bu kuralları ne kadar güçlü bir şekilde destekliyorlar?

Sorumlu davranış: Eğer destekliyorlarsa, iyi. Desteklemedikleri yerde onlara neden desteklemeleri gerektiğini öğretin.

Soru 3: Bu kuralların ihlali halinde, ne tür bir disiplin cezası uygulanacağını biliyorlar mı?

Sorumlu davranış: Eğer biliyorlarsa, iyi. Bilmedikleri yerde onlara öğretin.

Soru 4: Disiplin işlemlerinin adil olduğuna inanıyorlar mı?

Sorumlu davranış: Eğer inanıyorlarsa, iyi. İnanmadıkları yerde, ya disiplin işlemlerini gözden geçirin ya da onların algılarını düzeltin.

Soru 5: Disiplin suçlarını ihbar etmeye ne kadar istekliler?

Sorumlu davranış: Eğer istekliyseler, iyi. İstekli olmadıkları yerde, onları isteklendirmenin yollarını bulun.

Klockars ve arkadaşları (2005: 8-9), çalışmaları neticesinde, polis yöneticilerinin polis bütünlüğünü nasıl artırabileceklerine yönelik aşağıdaki önerilerde bulunmuşlardır: 
(1) Bir polis örgütündeki bütünlük, o polis örgütünün kültürü tarafından şekillenmektedir. Polislerin örgütsel ve mesleki kurallara uymalarını teşvik etmek için, polis örgütlerinin, bütünlüğün örgütsel ve mesleki bir sorumluluk olduğunu çalışanlarına benimsetmeleri, bireysel etik veya ahlakın önemini vurgulamalarından daha etkilidir.

(2) Polis örgütleri tarafından, polis disiplin sistemine yönelik kurallar ayrıntılı bir şekilde düzenlenmeli ve polisler disiplin sisteminin işleyişi konusunda eğitilmelidir.

(3) Polis disiplin suçlarına karşı; disiplin soruşturması açılması, disiplin suçlarının soruşturulması ve cezalandırılmasında görev alan polis yöneticilerinin tavrı, polislere, disiplin suçlarının örgüt tarafından ne kadar ciddiye alındığını gösterecektir.

(4) Polis yöneticileri, tüm polisleri, polis disiplin suçlarını ihbar etmeye kesinlikle zorunlu tutmalıdır. Meslektaşlarının disiplin suçlarını bildirmek için öne çıkan polislere, anonimlik ve gizlilik garantisi verilmesinin yanı sıra onları ödüllendirmek de ihbar için etkili bir yöntem olabilir. Yöneticiler; örgüt içindeki çeşitliliği teşvik ederek, terfi eden polislerin görev yerini değiştirerek ve polisleri zaman zaman farklı birimlere ve bölgelere nakil ederek, görevin kötüye kullanılmasına yol açan bağların gücünü zayıflatabileceklerdir.

Diğer taraftan polis bütünlüğünü, ne olmadığı üzerinden tanımlayan birçok çalışmada, "polis bütünlüğü" ya "yozlaşmış olmamak" ya da "meslekten sapmamak" ile ilişkilendirilmektedir. Örneğin Jennifer O'Connor Boes ve arkadaşları polis bütünlüğünü ne olmadığı üzerinden türlerine ayırarak tanımlamaya çalıșan bilim insanlarındandır. Boes ve arkadașları, "Police Integrity: Use of Personality Measures to Identify Corruption-Prone Officers" (Polis Bütünlüğ̈: Yolsuzluğa Meyilli Polis Mensuplarını Tanımlamak için Kişilik Ölçülerinin Kullanımı) başlıklı çalışmalarında, polis bütünlüğü ihlallerini, şu başlıklar altında türlerine ayırarak sınıflandırmışlardır; (1) tehlikeli görevlerdeki polis mensupları ile ilgili gizli bilgilerin ihlali, (2) suçlulara yardımcı olmak amacıyla gizli bilgilerin ihlali (3) rüşvet/rüşvetçilik, (4) koruma parası, (5) davayı düşürmek için kılıfına uydurma, (6) şehadeti kılıfına uydurma, (7) görev esnasında hırsızlık, (8) görev harici ihlaller, (9) zimmet/sahtekârlık, (10) çalışılan zaman dilimi üzerinde oynama (Boes vd., 1997: 58-59).

Polis bütünlügünü ne olduğu ve ne olmadığı üzerinden tanımlamaya çalışan karma yaklaşımı benimseyen bilim insanları da vardır. Hans Hovens'ın editörlüğünü yaptı̆̆ı ve 2014 yılında yayımlanan "Building Police Integrity- $A$ Post-Conflict Perspective" (Polis Bütünlüğünü İnşa EtmekBir Çatışma Sonrası Perspektifi) başlıklı kitabın "Building Police Integrity" (Polis Bütünlügüunü İnşa Etmek) başlıklı giriş bölümünde, pek çok kişi tarafından yapılmış bütünlük tanımlarının çoğunlukla, bütünlüğü üç yönden ele aldıkları ileri sürülmektedir. Hovens'ın analizine göre bütünlük kavramının kapsadığı üç yön şunlardır: (1) tutarlı, istikrarlı ve uyumlu olmak anlamında bütünlük; (2) ilk odak noktası sorumluluk olan profesyonellik anlamında bütünlük; (3) her zaman değerleri, norm ve kuralları izlemek anlamında bütünlük (Hovens, 2014: 16).

Hovens'a göre "bütünlük" genel olarak; sorumluluklarının bilinciyle, iyi veya doğru olan şeyi, erdemli bir şekilde, ilgili ahlaki değerlere, normlara ve temel kurallara uygun olarak ve istikrarlı bir şekilde yapmakla uyumluluk anlamına gelmektedir (Hovens, 2014: 17). Hovens, bütünlüğün hem kişilerin hem de örgütlerin kalitelerine ilişkin görüşlerin altını çizdiği fikrindedir. Hovens'a göre polis bütünlüğü; "Polis uygulama ve müdahalelerinin, geçerli ahlaki normlar ve değerlere, polisin ödev ve yükümlülüklerine göre yürütülmesi” anlamına gelmektedir. Bunun için önemli olan zemin ise geniş kapsamlı insan hakları, polis etiği, polise yön veren genel ahlaki ilkeler (yasallık, orantılılık, gereklilik ve hesap verilebilirlik) ve bütünlük ile kolektif çalışma gibi değerlerdir (Hovens, 2014: 21). Hovens, polis bütünlüğünü yukarıdaki çerçevede tanımladıktan sonra, ne olmadığı üzerinden de tanımlamaya çalışmıştır.

Hovens, polis bütünlügünü, ne olmadığı üzerinden tanımlarken, yanlış, kötü ve kusurlu polis davranışlarından bahsetmiştir. Bu çerçeveden polis bütünlüğü; rüşvet almamak, hediye kabul etmemek, adaleti yanıltmamak (sahte kayıt düzenlememek, yalancı şahitlik yapmamak, tanık ifadesini değiştirmemek ve delilleri karartmamak), gereksiz, orantısız veya aşırı güç kullanmamak, tutuklamalar esnasında kanunen el konulan şeyler (para ve/veya zapt olunan 
eşyalar) dâhil olmak üzere çalmamak veya sahtekârlık yapmamak ve sanıkların, şüphelilerin veya sivillerin kişisel bilgilerini veya ceza raporları bilgilerini veya adaletin tecellisini tehlikeye koyacak bilgileri yetkilendirilmemiş şekilde ifşa etmemek, kişisel çıkar (aile veya arkadaşlar için hizmetler de dâhil) sağlamak için kişilerle, kuruluşlarla, emlak ve menkul kıymetlerle ilgili (daha detaylı bilgi edinmek için) polis veri tabanında araştırma yapmak gibi polis sistemlerine yetkisi olmadan erişim sağlama eylemlerinden kaçınmak anlamlarına gelmektedir (Hovens, 2014: 22).

\section{Polis Bütünlügünün Bireysel, Grupsal ve Örgütsel Anlamları}

Bütünlük kavramı, literatürde bireysel, grupsal ve örgütsel anlamda kullanılabilmektedir. Mesleki anlamda grupsal ve örgütsel bütünlügün kullanılması, bütünlük kavramının ahlaki anlayışına dayalı bireysel bütünlüğü ifade ettiğinden, öncelikle grupsal ve örgütsel bütünlügün temeli olan bireysel bütünlüğün açılanmasını gerekli kılmaktadır. Bu çerçevede aşağıda bireysel, grupsal ve örgütsel polis bütünlüğü kavramlarının nasıl tanımlanabileceği üzerinde durulmuştur.

Bireysel Polis Bütünlügü: Bütünlük kavramı günlük kullanımda genellikle bireysel bütünlük (individual integrity) üzerine odaklanmaktadır. Bireysel bütünlük ile ilgili olarak, bütünlük kavramının genel bir ayrımı, kişisel bütünlük (personal integrity) ve ahlaki bütünlük (moral integrity) kavramları arasında sıklıkla çizilmektedir (McFall, 1987: 17; Van Luijk, 2004: 39; Vandekerckhove, 2007: 156). Kişisel bütünlük, bireyin kişisel değerlere ve ilkelere bağlı olduğunu ifade ederken; ahlaki bütünlük, kişinin ahlaki değerlere ve ilkelere bağlılığını anlatmaktadır (Van Luijk, 2004: 39). Açıkça, her iki anlayış da örtüşebilmekte, çünkü kişisel değerler de ahlaki olabilmektedir. Bireysel bütünlük için hem kişisel değerlerin hem de ahlaki değerlerin bütünleşmesi gerekmektedir. Diğer taraftan bütünlügün kamusal yönü de vardır. Peterson ve Seligman'a (2004) göre bütünlük; (1) bireysel bütünlük ve (2) kamusal bütünlük olmak üzere iki yönlüdür.

Bireysel bütünlük, bireyin sözlerinin, eylemlerinin ve içselleștirilmiş değerlerinin tutarlılığı ile ilgilenirken; kamusal bütünlük, daha çok sözlerin ve eylemlerin tutarlılığı ile ilgilenmektedir (Palanski ve Yammarino, 2007: 174). Bireysel ve kamusal bütünlük polislik mesleğine uygulandığında; polislerin, bireysel yönden üniforma giyen vatandaşlar olduklarına, kamusal yönden ise devlet memuru olduklarına işaret etmektedir. Bu durum, bireysel polis bütünlüğü anlamında, polislerin ideolojik görüşlerinin veya dinî inançlarının rol oynayabileceği anlamına gelmektedir. Genel olarak, polislerin kendi kişisel görüşlerini kendi özel hayatlarında deneyimlemeleri ve yaymaları gayet doğaldır. Fakat aynı şey görevleri başındayken geçerli değildir. Şöyle ki; bir polis, kişisel olarak, uygulanması gereken bir yasanın yanlış olduğunu düşünebilir. Fakat kamusal yönden, yani mesleki olarak, o yasanın uygulanması için tüm yasal ve makul talimatlara uymak zorundadır. Her ne kadar polislerin genel görüşü "her zaman (7/24) bütünlüğ̈̈mü korurum" șeklinde olsa da uygulamada bu fikir ikirciklidir (Hovens, 2014: 18). Polislik mesleğinin kamusal yönünü de hatırda tutarak, bireysel polis bütünlüğünü şu șekilde tanımlamak mümkündür: "Bir polisin; mesleki mevzuata, polis etiğine ve mesleki değerlere uygun davranması, davranışlarını içten gelerek, inanarak sergilemesi, söylediği sözlerin ve sergilediği davranışların tutarlı olması, mesleğe aykırı davranmaya sevk eden ayartmalara, mesleki sapma ve yozlaşmaya karşı direnç göstermesi ve bunların tümünü barındıran sağlam bir karaktere sahip olmasıdır."

Grupsal Polis Bütünlüğü: Grupsal boyutta bütünlük, aynı gruba mensup olanların, grubun ahlaki değerlerine bağlılıkları temelindeki bireysel bütünlüklerinden meydana gelen bir grup özelliğidir. Grubun ahlaki değerlerine bağlılık temelindeki bireysel bütünlük, bireyin gruba özgü ahlaki değerlerinin, sözlerinin ve eylemlerinin bireysel olarak tutarlılığı ile ilgilenirken; grupsal bütünlük, aynı gruba mensup olanların, grupsal ahlaki değerlerinin, sözlerinin ve eylemlerin grupsal olarak tutarlılı̆g ile ilgilenmektedir.

Leo Huberts (2013: 183), bir gruba mensup bir bireyin bireysel bütünlüğünün dört yönden ele alınabileceğini ileri sürmüştür: (1) "tamlık, tutarlılık ve uyum" olarak bütünlük, (2) "mesleki sorumluluk" olarak bütünlük, (3) "bozulmazlığı da içeren (bir takım) değer(ler)" olarak bütünlük

\section{R\&S}

Research Studies Anatolia Journal

Volume:3, Issue:4, October 2020 
ve (4) “amaca uygun ahlaki değerlere ve normlara uyum" olarak bütünlük. Hans Hovens'a göre ise bir gruba mensup bir bireyin bireysel bütünlügü üç yönden ele alınmalıdır: (1) "tutarlı, istikrarlı ve uyumlu olmak anlamında bütünlük", (2) "ilk odak noktası sorumluluk olan profesyonellik anlamında bütünlük" ve (3) "her zaman değerleri, norm ve kuralları izlemek anlamında bütünlük" (Hovens, 2014: 16).

Grupsal boyuttaki bütünlük, polis örgütündeki polislerin, zorunlu veya doğal süreçlerle oluşan meslektaş grupları bağlamında incelenebilir. Aynı birimde, şubede, karakolda, çalışma grubunda veya doğal olarak oluşan aynı meslektaş grubunda yer alan polisler, grup özelliği taşımaktadır. Grupsal boyuttaki bütünlük, polis grupları açısından değerlendirildiğinde, polislerin gerek kendi grupları içerisindeki ilişkilerinde gerek kendi gruplarının diğer polis grupları ile ilişkilerinde gerekse de bu grupların bağlı oldukları polis örgütü ve hizmet ettikleri halk ile ilişkilerinde; polis meslek ahlakına ve etiğine uygun olarak benimsedikleri ve sergiledikleri değerler, söylem ve eylemleri arasındaki tutarlılık ve polis sapma davranışlarına karşı sergiledikleri sağlam karakter olarak ifade edilebilir. Diğer bir ifadeyle grupsal polis bütünlüğü: Polislerin grupsal olarak; mesleki mevzuata, polis meslek etiğine ve mesleki değerlere uygun davranmaları, davranışlarını içten gelerek ve inanarak sergilemeleri, söyledikleri sözlerin ve sergiledikleri davranışların tutarlı olması, mesleğe aykırı davranmaya sevk eden ayartmalara, mesleki sapma ve yozlaşmaya karşı direnç göstermeleri ve bunların tümünü barındıran sağlam bir karaktere sahip olmalarıdır.

Örgütsel Polis Bütünlügü: Örgütsel boyutta bütünlük, aynı örgüte mensup olanların, örgütün ahlaki değerlerine bağllıkları temelindeki bireysel ve grupsal bütünlüklerinden meydana gelen bir örgüt özelliğidir. Örgütün ahlaki değerlerine bağlllık temelindeki bireysel bütünlük, bireyin örgüte ilişkin ahlaki değerlerinin, sözlerinin ve eylemlerinin bireysel olarak tutarlılığı ile ilgilenirken; grupsal bütünlük, aynı gruba mensup olanların, grupsal ahlaki değerlerinin, sözlerinin ve eylemlerin grupsal olarak tutarlılığı ile ilgilenmekte; örgütsel bütünlük ise aynı örgüte mensup olan gerek bireylerin gerekse grupların, örgütsel ahlaki değerlerinin, sözlerinin ve eylemlerinin örgütsel olarak tutarlılığı ile ilgilenmektedir.

Örgütsel bütünlük, örgüt çalışanlarının etik bütünlüğüne işaret etmekle birlikte, bir kurum olarak örgütün bütünlüğünü de ifade etmek için kullanılmakta ve örgütteki çalışanlar arasındaki etkileşimlerin, baskın normların, eylemlerin, karar verme süreç ve ilkelerinin ve verilen kararların etik kalitesini kapsamaktadır (Hong'tan akt. Kılıçoğlu, 2017: 493). Maak, örgütsel bütünlük için bağlılık, davranış, içerik, bağlam, tutarlılık, uyumluluk ve devamlılık olmak üzere toplam yedi bileșenin gerekli olduğunu vurgulamaktadır (Maak, 2008: 362). Örgütsel bütünlügü, Palanski ve Yammarino (2007), örgütsel sözlerin ve davranışların tutarlı olması şeklinde tanımlarlarken; Kurtz (2015), örgütün kendisini, kendine yol gösteren birtakım ilkelerle uyumlu bir şekilde yönetebilmesi olarak ifade etmektedir.

Örgütsel bütünlük; örgütün etik kuralları, prosedürleri, kültürü, misyonu ve vizyonu doğrultusunda tanımlanmış, kabul edilebilir davranışsal normların, söylem ve eylemde tutarlı bir şekilde uygulanmasını ifade etmekte ve örgütsel ahlaki ve etik değerlere devamlı bir şekilde bağlı kalınmasını gerektirmektedir. Örgütün söylem ve eylemleri arasında yüksek düzeyde bir tutarlılık olduğu zaman, örgütün yüksek düzeyde bir bütünlüğe sahip olduğu söylenmektedir (Palanski ve Yammarino, 2009). Örgütsel boyutta bütünlük, polis örgütü açısından değerlendirildiğinde, bireysel ve grupsal polis bütünlüğüne benzer şekilde, polislerin gerek polis örgütü içerisindeki karşılıklı ilişkilerinde gerek dâhil oldukları polis grubunun diğer polis grupları ile ilişkilerinde gerekse de hizmet ettikleri halk ile ilişkilerinde; polis meslek ahlakına ve etiğine uygun olarak benimsedikleri ve sergiledikleri değerler, söylem ve eylemleri arasındaki tutarlılık ve polis sapma davranışlarına karşı sergiledikleri sağlam karakter olarak ifade edilebilir. Diğer bir ifadeyle örgütsel polis bütünlügü: Polislerin örgütsel olarak; mesleki mevzuata, polis meslek etiğine ve mesleki değerlere uygun davranmaları, davranışlarını içten gelerek ve inanarak sergilemeleri, söyledikleri sözlerin ve sergiledikleri davranışların tutarlı olması, mesleğe aykırı davranmaya sevk eden ayartmalara, mesleki sapma ve yozlaşmaya karşı direnç göstermeleri ve bunların tümünü barındıran sağlam bir karaktere sahip olmalarıdır.

\section{$\mathrm{R} \& S$}

Research Studies Anatolia Journal

Volume:3, Issue:4, October 2020 


\section{POLIS SAPMASI SORUNUNA KARŞI BÜTÜNCÜL BİR YAKLAŞIM}

Literatürde polis sapması sorununa karşı polis örgütlerinin ya sapma ve yozlaşma ile mücadele stratejileri geliştirdikleri ya da bütünlügü koruma ve yükseltme stratejileri geliştirdikleri görülmektedir. Polis sapmasını önlemeye yönelik stratejiler ile polis bütünlügünü geliştirmeye yönelik stratejiler birleștirildiği zaman literatürde şu stratejilerin öne çıtı̆ğı görülmektedir; (1) kurumsal reform, (2) insan kaynakları yönetiminin etkin kullanımı, (3) polis etik kurallarını oluşturma ve destekleme, (4) bütünlük testi, (5) polis eğitimini geliştirme, (6) ceza ve ödül sistemini geliştirme, (7) güçlü iç ve dış denetim ve gözetim mekanizmaları geliştirme (Kutnjak Ivković, 2005; Prenzler, 2009; Newburn, 2015). Bu başlık altında söz konusu stratejilere yer verilmiştir.

\section{Kurumsal Reform}

Polis örgütlerindeki sapma ve yozlaşma ile mücadele ve bütünlügü koruma ve artırma adına geliştirilen stratejilerin önemli bir bölümü; geleneksel bürokratik hiyerarșik yapıları değiștirip azaltmaya, böylece performansı iyileștirmeye, halka hizmeti kolaylaştırmaya, etkinlik ve verimliliği artırmaya odaklanılan kurumsal reform stratejileridir (Punch, 2003; Fitzgerald, 1987; Fleming ve Lafferty, 2000; Newburn, 2015). Örneğin; toplum destekli polislik uygulamaları, ihtiyaç duyulan yeni birimlerin hızlıca ve yasal zemin temelinde kurulması ve geliştirilmesi, polislik hizmetlerinin mümkün olduğunca merkezden yerele aktarılması gibi stratejilerdir. $\mathrm{Bu}$ stratejilerin oluşturulması, geliştirilmesi ve uygulamaya konulması için polis örgütleri içerisindeki AR-GE birimlerinin etkin ve verimli bir şekilde işletilmesi son derece önemlidir.

\section{İnsan Kaynakları Yönetiminin Etkin Kullanımı}

Literatürde öne çıkan bir diğer strateji, işe alım/seçim sürecini geliştirme, polis uygulama ve müdahalelerine yönelik her alanda resmî politikalar oluşturma, söz konusu resmî politikaların yazılı hâle dönüștürülmesi, örgüt mensupları tarafından resmî kuralların, politika ve prosedürlerin benimsenmesini sağlama ve uygulanmasını destekleme, görev yeri dağılımlarında, nakiller ve terfilerde liyakati ön planda tutma, yozlaşmaya karşı toleranssız bir kültür (etik iklim) oluşturma, geliştirme ve sürdürme gibi faaliyetleri hızlıca hayata geçiren insan kaynakları yönetiminin etkin kullanımı stratejisidir (Botello ve Rivera, 2000; Kutnjak Ivković, 2005; Palmiotto, 2005; Newburn, 2015).

\section{Polis Etik Kurallarını Oluşturma ve Destekleme}

Genel olarak birçok demokratik ülke, polis etik kurallarını oluşturmuştur. Bu stratejide öne çıkan husus, örgütlerin; polis etik kurallarını sadece oluşturmalarının yeterli olmadığı, ayrıca polis etik kurallarını benimsetmeleri, içten gelerek uygulanmasını sağlamaları ve polis etik kurallarına aykırı davranışların daima karşısında yer almaları gerektiğidir (Kleinig, 1996; Newburn, 1999; Klockars vd., 2004). Bu çerçevede gelişmiş demokratik ülkelerde polis etik kurallarının örgüt bünyesinde içselleștirilmesi, etik davranışların teşvik edilip desteklenmesi ve etik dışı davranışların ise önlenmesine yönelik, Etik Yönetim Kurulu, Etik Komitesi, Şikâyet Takipçisi, Etik Uzmanı gibi kurumsal yapıların oluşturulduğu görülmektedir.

\section{Bütünlük Testi}

Literatürde öne çıkan stratejilerden bir diğeri, polis örgütleri tarafından polis mensuplarına uygulanan bütünlük testleridir. Söz konusu testler ile polis mensuplarına, olușturulan senaryolar çerçevesinde çeșitli cezbedici suç işleme fırsatları (yetki yozlașması, rüșvet, fırsat hırsızlığı, komisyonculuk gibi) sunulmaktadır. Gözetlendiğini bilmeyen polis mensupları, bu firsatlara karşı koyamamaları ve kapılıp gitmeleri durumunda testi geçememekte ve işlerine son verilmektedir. Bütünlük testleri, polis mensuplarının sapma ve yozlaşmaya meyilli olup olmadıklarını ortaya çıkarması bakımından son derece önemlidir (Marx, 1992). 


\section{Polis Eğitimini Geliştirme}

Polis sapması ve yozlaşması ile mücadele ve polis bütünlügünü koruma ve artırmaya yönelik stratejiler geliştiren hemen hemen bütün polis örgütlerinde, polis temel eğitimi ve hizmet içi eğitimlerin odağında; insan hakları, temel hak ve özgürlükler, polis etiği ve polis bütünlügü yer almakta, eğitimler esnasında mesleğin vakar ve onuruna vurgu yapılmakta, sorumluluk bilinci geliştirilmekte ve öğrenen merkezli, senaryolu, teoriden ziyade pratiğe odaklanılan eğitim müfredatları uygulanmakta ve bu müfredatlar sürekli geliştirilmektedir (Kutnjak Ivković, 2005; Prenzler, 2009; Newburn, 2015). Polis eğitimine yönelik stratejilerin oluşturulması, geliștirilmesi ve uygulamadaki ihtiyaçlara cevap verebilmesi için Polis Akademilerine ve Polis Okullarına önemli görevler düşmektedir.

\section{Ceza ve Ödül Sistemini Geliştirme}

Literatürde öne çıkan bir diğer strateji ceza ve ödül sisteminin geliştirilmesidir (Kutnjak Ivković, 2005; Newburn, 2015). Bu stratejide bir yandan konusu suç (disiplin suçu ve/veya adli suç) teşkil eden polis sapma davranışlarının etkin ve şeffaf bir şekilde soruşturulması, kovuşturulması ve sonuçlandırılmasına yönelik caydırıcı bir ceza sistemi öngörülürken, diğer yandan sapma ve yozlaşmaya karşı koyan, polis bütünlüğüne sahip polislerin ödüllendirilmesine yönelik teşvik edici bir ödül sistemi öngörülmektedir. Stratejinin ceza boyutunda, disiplin suçları yönünden, örgütün işlenen suçlardan haberdar olma isteğinin olması, soruşturma ve kovuşturmanın tarafsız ve bağımsız olması, sistemin sunulan şehadete göre beraat veya mahkûmiyete fırsat vermesi, disiplin cezalarının etkin, caydırıcı ve mesleğe yeniden kazandırıcı olması, polis bütünlüğünden yoksun olunan alanlarda eğitim, stres yönetimi, iletişim becerileri, psikolojik danışmanlık ve rehberlik gibi onarıcı hizmetler sunulması önem arz etmektedir. Stratejinin ceza boyutunda, adli suçlara yönelik olarak, polis şikâyet mekanizmasının halka güven veren kurumsal ve etkin bir yapıda olması önem arz etmektedir. Stratejinin ödül boyutunda; polis sapmasına ve yozlaşmasına karşı koyan polislere örgüt tarafından önem verildiği ve takdir edildiğinin gösterilmesi bütünlüğe sahip polisleri onurlandırırken, diğer polisleri de polis bütünlüğüne uygun davranmaya teşvik edecektir.

\section{Güçlü İç ve Dış Denetim ve Gözetim Mekanizmaları Geliştirme}

Literatürde öne çıkan bir diğer strateji, güçlü iç ve dış denetim ve gözetim mekanizmaları oluşturmak ve bu mekanizmaları sürekli aktif hâlde tutarak geliştirmektir. Kamera kullanımı (arama, tutuklama, ifade alma gibi anlar ve hücreler gibi alanlar), reaktif ve proaktif araştırma ve soruşturmalar, polis sapma ve yozlaşmasını kurum içi ihbar, erken uyarı ve müdahale, yozlaşma yönünde eğilimi gözetleme, yozlaşmaya karşı fırsatları kısıtlama, hesap verebilirlik, önleyici kontrol ile ilgili mekanizmalar birçok demokratik devletin polis örgütlerinde iç denetim ve gözetim stratejileri olarak öne çıkmaktadır (Sherman, 1983; Kutnjak Ivković, 2005; Prenzler, 2009; Newburn, 1999). Güçlü iç denetim ve gözetim mekanizmalarının geliştirilmesine yönelik stratejilerin oluşturulması, geliştirilmesi ve çağın gereklerine cevap verebilmesi için polis örgütlerinin denetim ve kontrol birimlerine önemli görevler düşmektedir. Diğer taraftan polis aleyhine şikâyetleri araştırma ve soruşturmaya yönelik dış mekanizmalar ile polis sapması ve yozlaşmasının durumu ile ilgili bilgi ve haberleri paylaşarak toplumda farkındalık oluşturmaya yönelik mekanizmalar da güçlü dış denetim ve gözetim stratejileri olarak literatürde öne çlkmaktadır (Sherman, 1978; Chan, 1999; Newburn, 2015).

\section{SONUÇ}

Polislerin, gerek iç güvenlik sistemi kapsamındaki emniyet ve asayiş ile ilgili idari görevlerini gerekse ceza adalet sistemi içerisindeki adli görevlerini yerine getirir ve yetkilerini kullanırlarken polis bütünlügü içerisinde hareket etmeleri ve polis sapma davranışı sergilememeleri gerekmektedir. Fakat polislerin sapma davranışı sergilemeleri ve suç işlemeleri, polisliğin başlangıcından beri var olan küresel bir sorun olarak varlığını sürdürmektedir.

Mesleğe yeni katılan polisler, polis örgüt kültürü, sosyalizasyon süreçleri, mesleki görevler ve yapısal örgütlenme bağlamında, dâhil oldukları küçük polis gruplarında polis sapma 
davranışlarını öğrenerek benimsemektedir. Polis sapma davranışı sergileyen sapkın polislere karşı, diğer polislerin ve toplumun tepki göstermemesi üzerine, zamanla sapkın polisler meslekten daha fazla sapmakta, bozulmakta, yozlaşmakta ve suç işlemekte, diğer polislerin sapma sürecine girmesine de neden olmaktadırlar. Görevi suçları önlemek olan polisin, kendisinin suç işler duruma gelmesi, sunulan polislik hizmetlerinin kalitesini ve polise duyulan güveni de olumsuz yönde etkilemektedir.

Polis sapması sorunu, önceleri bireysel bir sorun olarak görülmüş, polislik mesleğinin, yolsuzluk da dâhil olmak üzere sapmaya yatkın bireyleri cezbettiği; bu nedenle, bireysel olarak ahlaki açıdan kusurlu tüm bireylerin polis olmasının önlenmesinin ve hâlihazırda eğer polis örgütünde iseler bu polislerin cezalandırılarak polis örgütünden atılmalarının polis sapması sorununu çözeceği savunulmuştur. Bu yaklaşıma, polis mensuplarının birer suçlu olarak polis örgütlerine katılmadıkları, fakat polis alt kültürü ve grupsal mesleki sosyalleşme süreci içinde birer sapkın polise dönüştükleri tezi ile karşı çıkılmıștır. Tarihsel süreçte polis sapmasının grupsal olduğu tezini, polis örgüt kültürü teorisi üzerinden polis sapmasının grupsaldan da öte örgütsel olduğu tezi takip etmiştir. Polis sapmasının bireysel, grupsal ve örgütsel olduğu tezlerinin çözüm önerileri, genel olarak cezalandırmaya ve polis sapmasının önlenmesine yönelik mücadele stratejileri üzerine odaklanmıștır.

Polis bütünlüğü yaklaşımı, polis sapması sorununa karşı alternatif bir çözüm önerisi olarak ortaya çıkmıştır. Otuz yıla yakın bir süredir $A B D$ ve birçok $A B$ ülkesinde polis sapması sorunu üzerine polis bütünlügü yaklaşımıyla çok sayıda bilimsel çalışma yapıldığı görülmektedir. Bu yaklaşım, polis bütünlügünün bireysel, grupsal ve örgütsel anlamlarına ve polis bütünlüğünü her düzeyde korumaya ve geliştirmeye yönelik resmî kurallar koyma, eğitim, gelişim, denetim ve gözetim stratejileri üzerine odaklanmıştır.

$\mathrm{Bu}$ çalışma ile Türkçe literatürde ilk kez polislik mesleği açısından bütünlüğün teorik bir incelemesi sunulmaya çalışllmıştır. Bu inceleme yapılırken; bütünlük olgusunun kavramsal analizi, polis sapmasından polis bütünlügüne uzanan tarihsel süreç, polis bütünlügünün tanımlanmasına yönelik yaklaşımlar ve polis bütünlüğünün bireysel, grupsal ve örgütsel anlamları ortaya konulmuştur. Çalışma ayrıca polis sapması sorununa karşı bütüncül bir mücadele stratejisi geliştirilmesi gerektiğini de ortaya koymaktadır. Polis sapması sorununa karşı dünyada öne çıkan polis sapmasını önleme ve polis bütünlüğünü geliştirme stratejileri tek bir çatı altında birleștirilerek incelendiğinde şu stratejilerin öne çıktığı görülmektedir; kurumsal reform, insan kaynakları yönetiminin etkin kullanımı, polis etik kurallarını oluşturma ve destekleme, bütünlük testi, polis eğitimini geliştirme, ceza ve ödül sistemini geliştirme, güçlü iç ve dış denetim ve gözetim mekanizmaları geliştirme. Çalışma, polis bütünlüğünün önemine vurgu yapmakta ve polis sapması sorununa karşı bütüncül bir strateji geliştirilmesi gerektiğini ileri sürmektedir.

Polis bilimleri alanında İngilizce literatürde hem polis sapması hem de polis bütünlüğü üzerine çok sayıda nicel ve nitel bilimsel araştırma ve yayın bulunmasına rağmen Türkçe literatürde bu alanda yapılan çalıșmalar neredeyse yok denecek kadar azdır. Polis sapması küresel bir sorundur ve bu soruna yönelik hem polis sapması ve yozlaşmasını önlemeye hem de polis bütünlüğünü koruma ve geliştirmeye yönelik Türkiye özelinde ve Türkçe literatürde de çalışma yapılmasının bir ihtiyaç olduğu değerlendirilmektedir.

\section{KAYNAKÇA}

American Heritage Dictionary of the English Language, 4th edition, (Erişim), 20 Haziran 2020 (http://www.yourdictionary.com/integrity).

Barker, T. (1977). “Peer Group Support for Police Occupational Deviance”, Criminology, 15(3): pp. 353-366.

Benjamin, M. (1990). Splitting The Difference: Compromising And Integrity In Ethics And Politics, First Edition, USA: University Press of Kansas.

Bews, N.F. \& Rossouw, G.J. (2002). "A Role for Business Ethics in Facilitating Trustworthiness", Journal of Business Ethics, (39): pp. 377-389. 
Boes, J. O., Chandler, C. J., \& Timm, H. W. (1997). Police integrity: Use of personality measures to identify corruption-prone officers, (No. PERS-TR-97-003).

Botello, N. A., \& Rivera, A. L. (2000). "Everything in This Job Is Money: Inside the Mexican Police", World Policy Journal, 17(3): pp. 61-70.

Carter, S. L. (1996). Integrity, New York: Basic Books.

Chan, B.L. (1999). "Governing Police Practice: Limits of the New Accountability", British Journal of Sociology , (50): pp. 251-270.

Cooper, T. L. (1994). "The Emergence of Administrative Ethics as a Field of Study in the United States", (Ed. Terry L.C.) Handbook of Administrative Ethics. New York: Marcel Dekker.

Cox, D.; La Caze, M. \& Levine, M. P. (2003). Integrity and the Fragile Self, First Edition, Aldershot, Hants: Ashgate Pub Ltd.

Devellioğlu, F. (1984). Osmanlıca Türkçe Ansiklopedik Lügat, Ankara: Aydın Kitabevi.

Duska, R. F. (2005). "A look at integrity in financial services”, Journal of Financial Service Professionals, 59(5): p. 26.

$\begin{array}{lllll}\text { Etimoloji Türkçe, } & \text { (Erişim), } & 25 & \text { Haziran }\end{array}$ (https://www.etimolojiturkce.com/kelime/b\%C3\%BCt\%C3\%BCn,).

Fitzgerald, G.E. (1987). "Commission of Inquiry into Possible Illegal Activities and Associated Police Misconduct", Report of an Inquiry Pursuant to Orders in Council, Queensland.

Fleming, J., \& Lafferty, G. (2000). "New management techniques and restructuring for accountability in Australian police organizations", Policing: An International Journal of Police Strategies \& Management., 23(2): pp. 154-168.

Goldsmith, A. (2001). "The Pursuit of Police Integrity: Leadership and Governance Dimensions”, Current Issues Criminal Justice, 13(2): pp. 185-202.

Hickman, M. J.; Greene, J. R. \& Piquero, A.R. (2004). Police Integrity and Ethics, Belmont CA: Wadsworth/Thomson Learning.

HMIC (Her Majesty's Inspectorate of Constabulary). (1999). "Police Integrity: England, Wales and Northern Ireland: Securing and Maintaining Public Confidence”, London: HMIC.

Hovens, H. (2014). "Building Police İntegrity", (Ed. Hans Hovens), Building Police Integrity: A Post-Conflict Perspective. Netherlands: Koninklijke Marechaussee, pp. 13-43.

Howell, J. M., \& Avolio, B. J. (1995). “Charismatic leadership: submission or liberation?”, Business Quarterly, (60): p. 62

Huberts, L. (2013). "Integrity of Governance: What It Is (Not) And What Is Next", (Eds. Goos M., A. Venkat R., Fanie C. \& Gavin W.), Good, Bad and Next in Public Governance, The Winelands Papers, The Hague: Eleven, pp. 183-208.

Jensen, M. C. (2009). "Integrity: Without it nothing Works", Rotman Magazine: The Magazine of the Rotman School of Management, pp. 16-20.

Kayabaşı, C. (2012). “KKTC'de Polis Teşkilatının Meşruiyet Seviyesi Üzerine Bir Araştırma”, Yüksek Lisans Tezi, Lefke Avrupa Üniversitesi Sosyal Bilimler Enstitüsü, KKTC, Lefke.

Kayabaşı, C. (2020). “Kuzey Kıbrıs Türk Cumhuriyeti'nde Polis Meşruiyeti Faktörlerinin Polisle İşbirliğine Etkisi", Doktora Tezi, Polis Akademisi Güvenlik Bilimleri Enstitüsü, Ankara.

Kayabaşı, O. (2012). “KKTC Polis Örgütü Etikliğinin Toplumsal Algılanma Düzeyi Üzerine Bir Araștırma”, Yüksek Lisans Tezi, Lefke Avrupa Üniversitesi Sosyal Bilimler Enstitüsü, KKTC, Lefke. 
Kayabaşı, O. (2017a). "The Contours of Police Integrity in the Turkish Republic of Northern Cyprus", (Eds. Abidin Temizer and Sevilay Özer), II. International Symposium on Multidisciplinary Studies (ISMS), 18-21 May 2017, Rome/Italy (Symposium Book- Social Sciences) Volume I, Ankara: Gece Kitaplığı, pp. 153-193.

Kayabaşı, O. (2017b). "Police Integrity in the Turkish Republic of Northern Cyprus: Narcotics and Prevention of Smuggling Directorate Police Officers' Perceptions", Turkish Journal of Security Studies, 19 (Special Issue) pp. 100-129.

Kayabaşı, O. (2018a). "Police Integrity in the Turkish Republic of Northern Cyprus: Criminal Investigation Directorate Police Officers' Perceptions", The Journal of Academic Social Science Studies, 67(Spring III), pp. 509-528.

Kayabaşı, O. (2018b). "Police Integrity in the Turkish Republic of Northern Cyprus: Traffic Directorate Police Officers' Perceptions", (Eds. Hasan Babacan, A. Șevki Duymaz and Abidin Temizer), III. International Symposium on Multidisciplinary Studies (ISMS), 10-11 November 2017, Ankara/Turkey, Multidisciplinary Studies-3 (Social Sciences) Ankara: Gece Kitaplığı, pp. 459-488.

Kayabaşı, O. (2018c). "Police Integrity in the Turkish Republic of Northern Cyprus: Guzelyurt Police Directorate Police Officers' Perceptions”, (Eds. Hasan Babacan, A. Şevki Duymaz and Abidin Temizer), III. International Symposium on Multidisciplinary Studies (ISMS), 10-11 November 2017, Ankara/Turkey, Multidisciplinary Studies-3 (Social Sciences) Ankara: Gece Kitaplığı, pp. 489-515.

Kayabaşı, O. (2018d). "Polis Meslek Ahlakı Bütünlüğü Üzerine Karşılaştırmalı Bir Bakış", Akademik Sosyal Araştırmalar Dergisi, 6(66): ss. 542-563.

Kayabaşı, O. (2019a). “Polis Sapmasına Karşı Polis Bütünlüğü Perspektifinden Kuzey Kıbrıs Türk Cumhuriyeti Polis Örgütü”, Doktora Tezi, Polis Akademisi Güvenlik Bilimleri Enstitüsü, Ankara.

Kayabaşı, O. (2019b). "Örgütsel Polis Bütünlüğü ile Grupsal Polis Bütünlüğü Üzerine Karşılaştırmalı Bir Bakış: Kuzey Kıbrıs Türk Cumhuriyeti Polis Örgütü ile Lefke Polis Karakolu Örneği”, II. Lefke Kent Sempozyumu, 18-20 Aralık 2019, Lefke.

Kayabaşı, O. \& Tekiner, M. A. (2017a). “Kuzey Kıbrıs Türk Cumhuriyeti’nde Sürekli İkamet Edenlerin Polis Meslek Etiği Kapsamında Polis Algısının Ölçülmesi”, Türk İdare Dergisi, 89(485): ss. 665-694.

Kayabaşı, O. \& Tekiner, M. A. (2017b). “Kuzey Kıbrıs Türk Cumhuriyeti Polis Örgütünün Polis Meslek Ahlakı Bütünlüğü”, (Eds. Esra Aydın, Papatya Sevgin Bıçakçı \& Erdem Kırkbeşoğlu) 25. Ulusal Yönetim ve Organizasyon Kongresi Bildiriler Kitabı, Ankara: Başkent Üniversitesi, ss. 657-662.

Kılıçoğlu, G. (2017). "Örgütsel ikiyüzlülük ve bütünlüğün Türkiye bağlamında incelenmesi: Teorik bir çözümleme”, Kuram ve Uygulamada Eğitim Yönetimi Dergisi, 23(3): s. 465-504.

Kirkpatrick, S. A., \& Locke, E. A. (1991). “Leadership: do traits matter?”, The Executive, 5(2): pp. 48-60.

Kleinig, J. (1996). The Ethics of Policing, Cambridge, UK: Cambridge University Press.

Klockars, C. B.; Kutnjak Ivković, S. \& Haberfeld, M. R. (2004). "The Contours of Police Integrity”, (Eds. Carl B. Klockars, Sanja Kutnjak Ivković \& Maria R. Haberfeld), The Contours of Police Integrity, Thousand Oaks: Sage, pp. 1-18.

Klockars, C. B.; Kutnjak Ivković, S. \& Haberfeld, M. R. (2005). Enhancing Police Integrity, NIJ Research in Brief, Washington, D.C.: U.S. Department of Justice, National Institute of Justice, December 2005, NCJ 209269.

Klockars, C. B.; Kutnjak Ivković, S. \& Haberfeld, M. R. (2006). Enhancing Police Integrity, New 
York: Springer.

Klockars, C. B.; Kutnjak Ivković, S; Harver, W. E. \& Haberfeld, M. R. (1997). The Measurement of Police Integrity, Final Report Submitted to the U.S. Department of Justice, Office of Justice Programs, National Institute of Justice.

Koehn, D. (2005). “Integrity as a business asset”, Journal of Business Ethics, 58(1-3): pp.125-136.

Kurtz, R. S. (2015). “Organizational Deviance, Integrity, and Regulation: The 2008 MT Tintomara Spill”, Public Integrity, 17(1): pp. 75-89.

Kutnjak Ivković, S. (2005). Fallen Blue Knights, New York: Oxford University Press.

Lowe, K. B., Cordery, J., \& Morrison, D. (2004). "A model for the attribution of leader integrity: Peeking inside the black box of authentic leadership", In Gallup Leadership Institute conference, Lincoln, NE.

Maak, T. (2008). "Undivided Corporate Responsibility: Towards A Theory of Corporate Integrity", Journal of Business Ethics, 82(2): pp. 353-368.

Marx, G. T. (1992). "When the guards guard themselves: Undercover tactics turned inward", Policing and Society: An International Journal, 2(3): pp. 151-172.

McFall, L. (1987). "Integrity", Ethics: An International Journal Of Social, Political, and Legal Philosophy, 98(1): pp. 5-20.

Merriam-Webster Online Dictionary, (Erişim), 23 Mayıs 2020, (http://www.merriamwebster.com/dictionary/integrity).

Moore, M. (1997). “Epilogue”, (Eds. Stephen J. G. \& Phyllis M. D.), Police Integrity: Public Service with Honor: A Partnership Between the National Institute of Justice and the Office of Community Oriented Policing Services, U.S. Department of Justice, pp. 59-70.

Morrison, A. (2001). "Integrity and global leadership". Journal of Business Ethics, 31(1): pp. 6576.

Newburn, T. (1999). "Understanding and Preventing Police Corruption: Lessons from The Literature", Police Research Series 110, Home Office Policing and Reducing Crime Unit Research, Development and Statistics Directorate, London UK.

Newburn, T. (2015). Literature Review: Police Integrity and Corruption, LSE Research Online.

O'Connor, T. R. (2005). Police Deviance and Ethics, Mega Links in Criminal Justice.

Özkaya, Ö. (2019). Cumhurbaşkanlığı Hükümet Sisteminde İdarenin Bütünlüğü İlkesi, Ankara: Adalet Yayınevi.

Pagon, M. (2000). Policing in Central and Eastern Europe: Ethics, Integrity, and Human Rights. Ljubljana: College of Police and Security Studies.

Paine, L. S. (2005). “Integrity”. (Eds. Werhane, P.H. \& Freeman, R. E.), The Blackwell Encyclopedia of Management: Business Ethics, (2nd edition), Blackwell Publishing, Malden, MA. pp. 247249.

Palanski, M.E. \& Yammarino, F.J. (2007). "Integrity and Leadership: Clearing he Conceptual Confusion", European Management Journal, 25(3): pp. 171-184.

Palanski, M.E. \& Yammarino, F.J. (2009). "Integrity and Leadrship: A Multi-level Conceptual Framework", The Leadership Quarterly, (20): pp. 405-420.

Palmiotto, J. M. (2005). "Controling Corruption in the United States”. (Eds. R. Sarre, D. Das \& H.J. Albrecht), Policing Corruption: International Perspectives, London: Lexington Books.

Peterson, C. \& Seligman, M. E. P. (2004). Character strengths and virtues. Oxford University press: New York. 
Posner, B. Z. (2001). "What does it mean to act with integrity?", Teaching Business Ethics. (5): pp. 461-473.

Prenzler, T. (2009). Police Corruption: Preventing Misconduct and Maintaining Integrity, New York: Taylor \& Francis Group, LLC.

Punch, M. (2003). “Rotten Orchards: 'Pestilence', Police Misconduct and System Failure”, Policing and Society, 13(2): pp. 171-196.

Sherman, W. L. (1978). Scandal and Reform: Controlling Police Corruption, Berkeley, CA: University of California Press.

Sherman, W. L. (1983). "Scandal and Reform Thinking about Police", (Ed. Carl B. Klockars) Contemporary Readings, New York: McGrawHill.

Sherman, L. W. (1985). "Becoming Bent: Moral Careers of Corrupt Policemen”, (Eds. F. A. Elliston \& M. Feldberg), Moral Issues in Police Work, Totowa: NJ Rowman and Allanheld, pp. 253265.

Simons, T. L. (2002). "Behavioral integrity: The percieved alignment between managers' words and deeds as a research focus", Organization Science, (13): pp. 18- 35.

Simons, T. L.; Friedman, R.; Liu, L. A. \& Parks, J. M. (2007). "Racial differences in sensitvity to behavioral integrity: Attitudinal consequences, in-group effects, and 'trickle down' among black and non-black employees", Journal of Applied Psychology, 82(3): pp. 434- 443.

Stoddard, E. R. (1968). "Informal Code of Police Deviancy: A Group Approach to Blue-Coat Crime", Journal of Criminal Law, Criminology \& Police Sciences, 59(2): pp. 201-213.

Taylor, G. \& Gaita, R. (1981). "Integrity”, Proceedings of the Aristotelian Society Supplementary Volume, Oxford Academic, 55(1): pp. 143-176.

Thompson, D. F. (1985). "The Possibility of Administrative Ethics”, Public Administration Review, pp. 555-561.

Tracey, J. B., \& Hinkin, T. R. (1994). "Transformational leaders in the hospitality industry". Cornell Hotel and Restaurant Administration Quarterly, 35(2): pp. 18-24.

Tureng - Turkish English Dictionary, (Erişim), 18 Haziran 2020, (https://tureng.com/tr/turkce-ingilizce/integrity).

Türkçenin Diriliş Hareketi Sözlüğü, (Erişim), 26 Haziran 2020, (http://turkcenindirilisi.com/tdh_turkce_sozluk_turkce_kelimeler_kokenbilim_etimoloji/ ).

Türk Dil Kurumu, (Erişim), 25 Haziran 2020, (http://www.tdk.gov.tr/index.php?option=com_gts\&arama=gts\&guid=TDK.GTS.5ab222 3e34d1e9.64529541).

Vandekerckhove, W. (2007). "Integrity: Talking the Waltk Instead of Walking the Talk", (Eds. Chris Carter, Stewart Clegg, Martin Kornberger, Stephan Laske \& Martin Messner), Business Ethics As Practice: Representation, Reflexivity And Performance, Cheltenham, UK, Northampton, USA: Edward Elgar Publishing Ltd., pp. 153-168.

Van Luijk, H. (2004). "Integrity In The Private, The Public, And The Corporate Domain”, (Ed. George G. Brenkert), Corporate Integrity And Accountability, London: Sage Publications, pp. 38-54.

Vicchio, S. J. (1997). “Ethics and Police Integrity: Some Definitions and Questions for Study”, (Eds. Gaffigan, Stephen J. \& Phyllis Mac Donald), Police Integrity: Public Service with Honor: A Partnership Between the National Institute of Justice and the Office of Community 
Oriented Policing Services, Washington, DC: National Institute of Justice, Department of Justice, pp. 11-17.

Westley, W. A. (1970). Violence and the Police, Cambridge, MA: MIT Press.

Worden, S. (2003). "The role of integrity as a mediator in strategic leadership: A recipe for reputational capital", Journal of Business Ethics, 46(1): pp. 31-44.

Yukl, G., \& Van Fleet, D. D. (1992). "Theory and research on leadership in organizations". (Eds. M. D. Dunnette \& L. M. Hough), Handbook of industrial and organizational psychology, pp. 147-197. Consulting Psychologists Press. 